\title{
Effect of Composted Rock Phosphate with Organic Materials on Yield, Nutrient Uptake and Soil Fertility after Harvest of Maize (Zea mays L.)
}

\author{
M.K. Mali, R.H. Meena* and Gajanand Jat \\ Department of Agricultural Chemistry and Soil Science, Rajasthan College of Agriculture, \\ (Maharana Pratap University of Agriculture and Technology), Udaipur - 313001, India \\ *Corresponding author
}

\begin{abstract}
A B S T R A C T
Keywords

Phosphorus rich compost,

DAP, SSP, PSB,

Vermiculture and Maize.

Article Info

Accepted:

17 May 2017

Available Online:

10 June 2017

A field experiment was conducted at Instructional Farm, Rajasthan College of Agriculture, Udaipur during Kharif 2013 to study the effect of phosphorus rich compost on yield, nutrient uptake and nutrient status in soil after harvest of maize. Results revealed that application of various sources and levels of phosphorus (DAP, SSP and PRC incubate with and without PSB and vermiculture) significantly increase grain, stover and biological yield of maize was recorded under treatment 25\% RDP through PRC + Vermiculture + PSB + 75\% RDP through DAP by $107.55,82.56$ and 91.96 per cent, respectively over control. Similarly, uptake of nitrogen, phosphorus and potassium by crop was significantly higher with the application of $25 \%$ RDP through PRC + Vermiculture + PSB + $75 \%$ RDP through DAP by $159.56,177.58$ and 141.51 per cent, respectively over control. However, maximum available nitrogen, phosphorus and potassium in soil were recorded under treatment $100 \%$ RDP through PRC + Vermiculture + PSB after harvest of maize crop as compared to all other treatments.
\end{abstract}

\section{Introduction}

Phosphorus $(\mathrm{P})$ is the major plant nutrient and considered one of the primary factor limiting crop yields (Zaidi et al., 2009). Therefore, application of phosphatic fertilizers is essentially required to maximize crop yields. The overall P use efficiency of applied phosphatic fertilizer such as SSP, DAP,TSP etc. is lower than optimal and only 15 to 20 per cent of applied phosphorus is recovered by the first crop, because of the formation of insoluble P compounds in soil (Vance, 2001). An important factor contributing to this low recovery is high $\mathrm{Ca}$ content in calcareous soils, which are very much prevalent in India. So addition of sufficient $\mathrm{P}$ through $\mathrm{P}$ fertilizers is direly needed.

The cost of conventional fertilizers like DAP, SSP is so high. Moreover, in India, continuously increasing the prices of such phosphatic fertilizers, consequently, it restrict their use by sizable poor farming community and also their scarcity at the right time of application mostly accounts for low $P$ fertilizers use by the farmers resulting in relatively low crop yields in India. This 
situation warrants the formulation of a cheaper and locally developed $\mathrm{P}$ product for field use.

For the production of phosphatic fertilizers only about 35 to 40 per cent of the requirements of raw material are being met through indigenous sources and rest is met through import in the form of rock phosphate, phosphoric acid and direct fertilizers (Tisdale et al., 1995). The total rock phosphate deposits in India are estimated to be about 300 MT (TIFAC, 2011) of which only a fraction of it (about 25\%) meets the specification of the fertilizer industry because of low grade $\mathrm{P}$ content (low grade). In Rajasthan, major sources of rock phosphate are Jhamarkotra (Udaipur) rock phosphate which is locally available source of phosphorus in Rajasthan. RP has good $\mathrm{P}$ content (28-30\%) but cannot be directly used as a fertilizer because of its poor release of $\mathrm{P}$ for the use of plant (Reddy et al., 2002). Rock phosphate is effective when applied directly to acidic soils. It cannot be used with the same levels of efficiency on alkaline calcareous soils. In alkaline soils of India, direct use of RP is not feasible because of its poor solubility. However, if RP is allowed to react with organic acids produced during composting, a major part of RP-P could be solubilizes for plant uptake (Singh and Reddy, 2011). It is well documented that during composting process of organic waste a variety of organic acids are released. The interaction of organic acids released during composting results in $\mathrm{P}$ solubilization from $\mathrm{RP}$ for plant uptake. The use of organic fertilizers made up of various composted materials, is now established as a key strategy not only for improving soil organic matter contents and nutrients supply to plants but also for reducing the input cost of mineral fertilizers and promoting healthier environments (Ahmad et al., 2006). Therefore, the availability of phosphorus from these rock phosphate could be improved through composting technology using FYM, agricultural wastes, crop residues, phosphate solubilizing bacteria (PSB) and earthworm (Vermiculture) to make available ' $\mathrm{P}$ ' in alkaline soil. This may imply that the low grade RP reserves of India could be used efficiently by preparing phosphate rich compost which not only economical but also environment friendly.

Maize (Zea mays L.) is an important cereal crop of India and plays a pivotal role in agricultural economy both as staple food for larger section of population, raw material for industries and feed for animals (mostly poultry). Currently, it is cultivated over an area of 9.40 million ha with 24.19 million tonnes production with an average yield of $25.40 \mathrm{q} \mathrm{ha}^{-1}$ contributing nearly 9 per cent in the national food basket (Anonymous, 2014). Rajasthan ranks first in respect of area, where in this crop occupies 1.05 million ha area with production of 1.95 million tonnes and productivity of $18.60 \mathrm{q} \mathrm{ha}^{-1}$ (Anonymous, 2014). The productivity is quite lower than other developed countries mainly due to suboptimal application of fertilizers and its cultivation on marginal lands. The phosphorus rich compost (PRC) being cheaper and eco-friendly and could be the alternatives of chemical fertilizers for improving both crop productivity and sustainability of the systems. Therefore, the present study was carried out with objective to study the effect of phosphorus rich compost on yield, nutrient uptake and available nutrient status in soil after harvest of maize in southern Rajasthan.

\section{Materials and Methods}

The experiment was conducted at the Instructional Farm, Rajasthan College of Agriculture, Udaipur during Kharif 2013. The site is situated at South-Eastern part of 
Rajasthan at an altitude of $579.5 \mathrm{~m}$ above mean sea level, at $24^{\circ} 35^{\prime} \mathrm{N}$ latitude and $74^{\circ} 42^{\prime}$ E longitude. The mean annual rainfall of the region is $610.2 \mathrm{~mm}$, most of which is contributed by south west monsoon from July to September. Maximum and minimum temperatures ranged between 27.1 to $32.6^{\circ} \mathrm{C}$ and 14.2 to $24.8^{\circ} \mathrm{C}$, respectively during kharif 2013. Before conducting the experiment, initial characteristics of the soil was determined by standards procedure as described by Jackson (1973). The soil of the experimental field was sandy clay loamy in texture, slightly alkaline ( $\mathrm{pH} 7.78)$, medium in organic carbon $(0.62 \%)$, nitrogen $(262 \mathrm{~kg}$ $\left.\mathrm{ha}^{-1}\right), \mathrm{P}_{2} \mathrm{O}_{5}\left(20.5 \mathrm{~kg} \mathrm{ha}^{-1}\right)$ and high in $\mathrm{K}_{2} \mathrm{O}$ $\left(432 \mathrm{~kg} \mathrm{ha}^{-1}\right)$ and sufficient amount of DTPA extractable micronutrients.

For the preparation of $\mathrm{P}$ rich compost, four pits of six feet length, three feet width and two feet depth were made. Raw materials like farm wastes and fresh cow dung were collected and mixed in the ratio of 1:1 on dry weight basis. Low grade rock phosphate $(16 \%$ $\mathrm{P}_{2} \mathrm{O}_{5}$ ) was procured from Rajasthan State Mines and Minerals Ltd., Udaipur, Rajasthan. The pits were filled with crop residue; FYM and Jhhamarkotra rock phosphate in the ratio of 10:1, respectively and mix them well. The mixed material was filled to all the four pits, and finally was add water for better composting. After twenty days of composting were release vermiculture in the two pits having treatment of worms and PSB. The organic material was composted and vermicomposted for three months and all pits was keep moist throughout the composting period.

The experiment was laid out in randomize block design having three replications with following 11 treatments T0 (Control), T1 (100\% RDP through DAP), T2 (100\% RDP through SSP), T3 (25\% RDP through PRC + $75 \%$ RDP through DAP), T4 (25\% RDP through $\mathrm{PRC}+\mathrm{PSB}+75 \% \mathrm{PDP}$ through DAP), T5 (25\% RDP through PRC + Vermiculture $+75 \%$ PDP through DAP), T6 (25\% RDP through PRC + Vermiculture + PSB $+75 \%$ RDP through DAP), T7 (100\% RDP through PRC), T8 (100\% RDP through PRC + PSB), T9 (100\% RDP through PRC + Vermiculture) and T10 (100\% RDP through PRC + Vermiculture + PSB). The field was prepared by cross cultivator followed by planking to obtain well pulverized soil tilth. During sowing $50 \%$ of total dose of $\mathrm{N}$ and full dose of $\mathrm{P}_{2} \mathrm{O}_{5}$ and $\mathrm{K}_{2} \mathrm{O}$ were applied as basal and remaining 50\% in 25-30 DAS.

The grain and stover yields were recorded after threshing the bundles of maize plants from each treatment. The plant samples were collected at harvest and analyzed for $\mathrm{N}, \mathrm{P}$ and $\mathrm{K}$ content in grain and stover.

Soil samples $(0-15 \mathrm{~cm})$ were collected after harvest. Total nitrogen was determined by Micro-Kjeldhal method (Snell and Snell, 1955), Phosphorus by Vanadomolybdate phosphoric acid yellow colour method (Jackson, 1973) and Potassium by flame photometer (Jackson, 1973). The collected soil samples were analyzed for $\mathrm{pH}$ using $\mathrm{pH}$ meter (1:2 soil: water suspension), electrical conductivity by conductivity meter (Richards, 1954) and organic carbon by rapid titration method (Piper, 1960).

Available $\mathrm{N}$ was estimated by alkaline permanganate method (Subbiah and Asija, 1956), available P by Olsen's method (Olsen et al.,1954) and available $\mathrm{K}$ by ammonium acetate extraction method (Richards, 1954). The data collected was analyzed statistically by using Fisher's analysis of variance technique and individual treatment means were separated by using least significant difference (RBD) test at 5 percent probability level. 


\section{Results and Discussion}

\section{Grain and stover yield}

The application of $\mathrm{P}$ sources significant influenced the grain and stover yields of maize (Table 1). Data shows that that application of $60 \mathrm{~kg} \mathrm{P}_{2} \mathrm{O}_{5} \mathrm{ha}^{-1}$ through DAP, SSP and PRC with and without PSB and Vermiculture and PRC with integration of inorganic $\mathrm{P}$ fertilizer significantly increased grain and stover yields of maize over the control. The crop fertilized with $25 \% \mathrm{P}$ through PRC + Vermiculture + PSB $+75 \% \mathrm{P}$ through DAP produced significantly higher grain yield by107.58, 19.07, 18.46 and 15.68 per cent, over T0 (Control), T3 (25\% RDP through PRC $+75 \%$ RDP through DAP), T7 (100\% RDP through PRC) and T9 (100\% RDP through PRC + Vermiculture), respectively.

However, it was observed at par with treatment T1 (100\% RDP through DAP), T2 (100\% RDP through SSP), T4 (25\% RDP through PRC + PSB $+75 \%$ RDP through DAP), T5 (25\% RDP through PRC + Vermiculture $+75 \%$ RDP through DAP), T8 (100\% RDP through PRC + PSB) and T10 (100\% RDP through PRC + Vermiculture + PSB). Similar trends were also observed under biological yield.

This may be attributed to the higher amount of total $\mathrm{P}$ present in composted rockphosphate with vermiculture and PSB had higher grain and stover yields than those without it. The effective utilization of different RPs in combination with vermiculture and PSB was obvious because these organisms secrete organic acids and enzymes which helped in bio-transformation of insoluble $\mathrm{P}$ to available form. Moreover, these increased the potentiality of more due to solubilization of both organic as well as inorganic $\mathrm{P}$ in soil.
The results corroborate the findings of Mishra et al., (1982), attributing the effect of rock phosphate enriched compost to the release of $\mathrm{P}$ from rock phosphate during decomposition and partially the additive effect of organics. Also the organics enriched with inorganic P, when added to soil are subjected to biological mineralization and there is a production of organic-P fractions as phosphor-humus complexes which easily supply nutrients to plants.

Opala et al., (2009) reported that integrated application of organic and inorganic phosphorus sources had significant positive role in the growth characteristics of maize.

These results are consistency with Hellal et al., (2013), and Lal et al., (2015) who found that yield was increased significantly by the application of RP composted with organic materials. Similar, results were also reported by Zafar et al., (2011), Vyas et al., (2012), Hellal et al., (2013), and Sepat and Rai (2013).

\section{Nutrient uptake}

Data on nitrogen, phosphorus and potassium uptake by maize as affected by RP composted organic material are given in table 2 . Total N, $\mathrm{P}$ and $\mathrm{K}$ uptake $91.86,20.18$ and $99.43 \mathrm{~kg} \mathrm{ha}^{-1}$ with $159.56 \%, \quad 177.58 \%$ and $141.51 \%$ increase, respectively over control was found in treatment where combination of $25 \%$ RDP through PRC + Vermiculture + PSB $+75 \%$ RDP through DAP (T6) which was statistically at par with $25 \%$ RDP through $\mathrm{PRC}+\mathrm{PSB}+75 \%$ RDP through DAP (T4), $25 \%$ RDP through PRC + Vermiculture + $75 \%$ RDP through DAP (T5) and 100\% RDP through PRC + Vermiculture + PSB (T10) in case of $\mathrm{N}$ and $\mathrm{P}$ uptake by maize. The minimum plant $\mathrm{N}$ uptake of $33.39 \mathrm{~kg} \mathrm{ha}^{-1}$ was noted in control. 
Awaad et al., (2009) reported that $\mathrm{N}$ uptake in plant increased by the combined application of phosphatic source such as RP composted fertilizers. Data regarding plant $\mathrm{P}$ uptake by maize revealed $177.58 \%$ significantly increase over control plot with $20.18 \mathrm{~kg} \mathrm{ha}^{-1} \mathrm{P}$ uptake, where $25 \%$ RDP through PRC + Vermiculture + PSB + 75\% RDP through DAP (T6) was used.

Table.1 Effect of phosphorus rich compost on yield of maize

\begin{tabular}{|c|c|c|c|c|}
\hline \multicolumn{2}{|c|}{ Treatments } & $\begin{array}{c}\text { Grain } \\
\text { Yield }\left(\mathbf{k g ~ h a}^{-1}\right) \\
\end{array}$ & $\begin{array}{c}\text { Stover } \\
\text { Yield }\left(\mathbf{k g ~ h a}^{-1}\right) \\
\end{array}$ & \multirow{2}{*}{$\begin{array}{c}\text { Biological } \\
\text { Yield }\left(\mathbf{k g ~ h a}^{-\mathbf{1}}\right) \\
5038\end{array}$} \\
\hline $\mathrm{T}_{0}$ & Control & 1895 & 3143 & \\
\hline $\mathrm{T}_{1}$ & $100 \%$ RDP through DAP & 3510 & 5137 & 8647 \\
\hline $\mathrm{T}_{2}$ & $100 \%$ RDP through SSP & 3440 & 5070 & 8510 \\
\hline $\mathrm{T}_{3}$ & $\begin{array}{l}25 \% \text { RDP through PRC }+75 \% \text { RDP } \\
\text { through DAP }\end{array}$ & 3303 & 4953 & 8256 \\
\hline $\mathrm{T}_{4}$ & $\begin{array}{l}25 \% \text { RDP through PRC }+ \text { PSB }+75 \% \\
\text { RDP through DAP }\end{array}$ & 3708 & 5483 & 9191 \\
\hline $\mathrm{T}_{5}$ & $\begin{array}{l}25 \% \text { RDP through PRC + Vermiculture + } \\
75 \% \text { RDP through DAP }\end{array}$ & 3590 & 5368 & 8958 \\
\hline $\mathrm{T}_{6}$ & $\begin{array}{l}25 \% \text { RDP through PRC }+ \text { Vermiculture }+ \\
\text { PSB }+75 \% \text { RDP through DAP }\end{array}$ & 3933 & 5738 & 9671 \\
\hline $\mathrm{T}_{7}$ & $100 \%$ RDP through PRC & 3320 & 4893 & 8213 \\
\hline $\mathrm{T}_{8}$ & $100 \%$ RDP through PRC + PSB & 3490 & 5133 & 8623 \\
\hline $\mathrm{T}_{9}$ & $100 \%$ RDP through PRC + Vermiculture & 3400 & 4965 & 8365 \\
\hline $\mathrm{T}_{10}$ & $\begin{array}{l}100 \% \text { RDP through PRC + Vermiculture } \\
+ \text { PSB }\end{array}$ & 3605 & 5338 & 8943 \\
\hline \multicolumn{2}{|c|}{$\mathrm{SEm} \pm$} & 175.71 & 260.61 & 287 \\
\hline \multicolumn{2}{|c|}{$\mathrm{CD}(5 \%)$} & 518.33 & 768.81 & 846 \\
\hline
\end{tabular}


Table.2 Effect of phosphorus rich compost on Nutrient uptake

\begin{tabular}{lccc}
\hline \multirow{2}{*}{ Treatments } & \multicolumn{3}{c}{ Nutrient uptake $\left(\mathbf{k g ~ h a}^{-1}\right)$} \\
\cline { 2 - 4 } & $\mathbf{N}$ & $\mathbf{P}$ & $\mathbf{K}$ \\
\hline $\mathrm{T}_{0}:$ Control & 35.39 & 7.27 & 41.17 \\
$\mathrm{~T}_{1}: 100 \%$ RDP through DAP & 77.73 & 17.10 & 86.01 \\
$\mathrm{~T}_{2}: 100 \%$ RDP through SSP & 75.67 & 16.69 & 84.17 \\
$\mathrm{~T}_{3}: 25 \%$ RDP through PRC + 75\% RDP through & 71.85 & 15.76 & 81.12 \\
$\mathrm{DAP}$ & & & \\
$\mathrm{T}_{4}: 25 \%$ RDP through PRC + PSB + 75\% RDP & 85.42 & 18.53 & 93.63 \\
through DAP & & & \\
$\mathrm{T}_{5}: 25 \%$ RDP through PRC + Vermiculture + 75\% & 81.97 & 17.62 & 90.76 \\
$\mathrm{RDP}$ through DAP & & & \\
$\mathrm{T}_{6}: 25 \%$ RDP through PRC + Vermiculture + PSB + & 91.86 & 20.18 & 99.43 \\
$75 \%$ RDP through DAP & & & \\
$\mathrm{T}_{7}: 100 \%$ RDP through PRC & 71.58 & 15.26 & 78.13 \\
$\mathrm{~T}_{8}: 100 \%$ RDP through PRC + PSB & 77.11 & 16.84 & 83.02 \\
$\mathrm{~T}_{9}: 100 \%$ RDP through PRC + Vermiculture & 73.75 & 16.13 & 79.93 \\
$\mathrm{~T}_{10}: 100 \%$ RDP through PRC + Vermiculture + PSB & 81.59 & 17.62 & 86.38 \\
SEm \pm & 4.54 & 1.01 & 3.21 \\
CD $5 \%)$ & 13.40 & 2.99 & 9.48 \\
\hline
\end{tabular}

Table.3 Effect of phosphorus rich compost on available nutrients status of soil after harvest of maize

\begin{tabular}{lccc}
\hline Treatment & $\begin{array}{c}\text { Available N } \\
\left(\mathbf{k g ~ h a}^{-1}\right)\end{array}$ & $\begin{array}{c}\text { Available } \\
\mathbf{P}_{\mathbf{2}} \mathbf{O}_{\mathbf{5}} \\
\left(\mathbf{k g ~ h a}^{-\mathbf{1}}\right)\end{array}$ & $\begin{array}{c}\text { Available } \\
\mathbf{K}_{\mathbf{2}} \mathbf{O} \\
\left(\mathbf{k g ~ h a}^{-\mathbf{1}} \mathbf{)}\right.\end{array}$ \\
\hline $\mathrm{T}_{0}:$ Control & 252.38 & 19.50 & 390.98 \\
$\mathrm{~T}_{1}: 100 \%$ RDP through DAP & 263.17 & 23.67 & 424.38 \\
$\mathrm{~T}_{2}: 100 \%$ RDP through SSP & 262.08 & 22.52 & 420.41 \\
$\mathrm{~T}_{3}: 25 \%$ RDP through PRC + 75\% RDP & 265.17 & 23.10 & 421.36 \\
through DAP & & & \\
$\mathrm{T}_{4}: 25 \%$ RDP through PRC + PSB + 75\% & 270.46 & 24.71 & 429.35 \\
RDP through DAP & & & \\
$\mathrm{T}_{5}: 25 \%$ RDP through PRC + Vermiculture & 267.08 & 24.12 & 425.21 \\
+ + 75\% RDP through DAP & & & \\
$\mathrm{T}_{6}: 25 \%$ RDP through PRC + Vermiculture & 274.58 & 24.89 & 431.36 \\
+ PSB + 75\% RDP through DAP & & & \\
$\mathrm{T}_{7}: 100 \%$ RDP through PRC & 268.42 & 23.34 & 427.52 \\
$\mathrm{~T}_{8}: 100 \%$ RDP through PRC + PSB & 278.92 & 25.66 & 447.50 \\
$\mathrm{~T}_{9}: 100 \%$ RDP through PRC + Vermiculture & 274.58 & 24.61 & 442.35 \\
$\mathrm{~T}_{10}: 100 \%$ RDP through PRC + & 290.04 & 26.12 & 455.58 \\
Vermiculture + PSB & & & \\
SEm \pm & 6.44 & 0.58 & 10.55 \\
CD (5\%) & 19.00 & 1.70 & 31.12 \\
\hline
\end{tabular}


This increased $\mathrm{P}$ uptake was followed by the treatments where 25\% RDP through PRC + PSB $+75 \%$ RDP through DAP was applied. Minimum plant $\mathrm{P}$ uptake of $7.27 \mathrm{~kg} \mathrm{ha}^{-1}$ was recorded in control where no fertilizer was applied. It is well documented that $\mathrm{P}$ uptake by crop largely depends on dry matter accumulation and concentration of $\mathrm{P}$ in plant parts at cellular level and increased availability of $\mathrm{P}$ in the soil due to solubilization of added phosphorus by $\mathrm{P}$ solubilizers through production of organic acids. These results are similar to findings of Ali et al., (2014) who reported that nutrients accumulation in plant were enhanced by the use of RP composted and inorganic materials. Erdal et al., (2000) also reported that accumulation increased in plant $\mathrm{N}$ and $\mathrm{P}$ when dung as organic material and chemical fertilizer was applied.

\section{Available nutrients after harvest of maize crop}

The available $\mathrm{N}, \mathrm{P}$ and $\mathrm{K}$ after harvested as influenced via residual effects of RP composted organic material are show in table 3. Data on soil available nitrogen content revealed that maximum $\left(290.04 \mathrm{~kg} \mathrm{ha}^{-1}\right)$ was received within the treatment of $100 \%$ RDP through PRC+ Vermiculture + PSB (T10) followed by the $100 \%$ RDP through PRC+ PSB (T8). The lowest nitrogen content in soil after maize crop harvest as $252.38 \mathrm{~kg} \mathrm{ha}^{-1}$ was recorded by treatment of control which was not fertilized (Table 3). Esilaba et al., (2000) investigated that the organic manure and NPK fertilizers improve the concentration of soil nitrogen. The highest available $\mathrm{P}$ content in soil was recorded as $26.12 \mathrm{~kg} \mathrm{ha}^{-1}$ by treatment $100 \%$ RDP through PRC + Vermiculture + PSB (T10) followed by the $100 \%$ RDP through PRC+ PSB (T8). Minimum $\mathrm{P}$ content $19.50 \mathrm{~kg} \mathrm{ha}{ }^{-1}$ was observed in the treatment of control without fertilized. Laskar et al., (1990) reported that rock phosphate alone and in combination with organic manure significantly enhance the content of organic $\mathrm{P}$ in soil. Wang et al., (1993) opined that in calcareous soil, addition of organic manures increased $\mathrm{P}$ availability and microbial activity while decreasing level of P-fixation. Available potassium ranged from 390.98 to $455.58 \mathrm{~kg} \mathrm{ha}^{-1}$ in soil after harvest of maize crop. The maximum available $\mathrm{K}$ was observed in the treatment $100 \%$ RDP through PRC + Vermiculture + PSB (T10). The results indicated that improvements in available potassium content came from $\mathrm{K}$ released from organic input of applied compost or from increased availability of native potassium following the addition of compost. Most of the simple cationic forms of nutrients present in the soil at any time are in exchangeable forms associated with clay minerals and the organic fractions of the soil, of which these can be rapidly exchanged with cations in the soil solution. These results are collaborated with findings of Ali et al., (2014) who reported that composted rock phosphate with organic material significantly increased the content of nutrients in soil.

The study revealed that composted of lowgrade rock phosphate along with organic material and phosphate solubilizing bacteria and earthworms helped to enhance the mobilization of unavailable $\mathrm{P}$ in rock phosphate to available forms of P. It has potential to improve crop production and nutrient uptake by crop. Post-harvest soil N, P and $\mathrm{K}$ concentrations were increased by the addition of composted rock phosphate with organic material. Thus, composted rock phosphate could be alternatives and viable technology to utilize low- grade rock phosphate and could be used successfully as cheaper and indigenous source of $\mathrm{P}$ fertilizer.

\section{Acknowledgement}

The authors would like to express their gratitude to the Rajasthan State Mines and 
Minerals Limited, Udaipur for providing financial help for this research.

\section{References}

Ahmad, R., Khalid, A., Arshad, M., Zahir, Z.A. and Naveed, M. 2006. Effect of raw (uncomposted) and composted organic waste material on growth and yield of maize (Zea mays L.). Soil Environ, 25: 135-142.

Ali, A., Sharif, M., Wahid, F., Zhang, Z., Shah, S.N.M., Rafiullah, Zaheer, S., Khan, F. and Rehman, F. 2014. Effect of Composted Rock Phosphate with Organic Materials on Yield and Phosphorus Uptake of Berseem and Maize. Am. J. Plant Sci., 5: 975-984.

Anonymous. 2014. Economic Survey, Ministry of Finance, Department of Economic Affair, Economic Division, Government of India. New Delhi, pp. 179-207.

Anonymous. 2014. Vital Agriculture Statistics, Directorate of Agriculture Rajasthan, Pp. 112-123.

Awaad, M.S., Rashad, A.A. and Bayoumi, M.A. 2009. Effect of farmyard manure combined with some phosphate sources on the productivity of Canola plants grown on a sandy soil. Res. J. Agril. and Bio. Sci., 5: 1176-1181.

Erdal, I., Bozkurt, M.A., Cimrin, K.M., Karaca, S. and Saglam, M. 2000. Effects of Humic Acid and Phosphorus fertilizer application on Growth and Phosphorus Uptake of Maize (Zea mays L.) Grown on a Calcareous Soil. Turkish J. Agril. Forest, 24: 663-668.

Esilaba, A.O., Reda, F., Ransom, J.K., Bayu, W., Woldewahid, G. and Zemichael, B. 2000. Integrated Nutrient Management Strategies for Soil Fertility Improvement and Striga Control in Northern Ethiopia. Afr. Crop Sci. J., 8: 403-410.
Hellal, F.A., Fuji, N. and Zewainy, R.M. 2013. Influence of phosphocompost application on phosphorus availability and uptake by maize grown in red soil of Ishigaki Island, Japan. Agril. Sci., 4(2): 102-109.

Jackson, M.L. 1973. Soils Chemical analysis. Prentice Hall Inc. Engle Cliffs, New Jersey.

Lal, Kanhaiya, Purohit, H.S. and Gurjer, K.L. 2015. Effect of Phosphorus rich Compost on Growth Parameters and Productivity of Blackgram (Vigna mungo). Ecoscan, VII: 249-252.

Laskar, B.K., De, G.K., Debnath, N.C. and Basak, R.K. 1990. Phosphorus availability and transformation from Mussoorie rockphophate in acid soils. Environ. Ecol., 8: 612-616.

Mishra, M.M., Kapoor, K.K. and Yadav, K.S. 1982. Effect of compost enriched with Mussoorie rock phosphate on crop yield. Indian J. Agri. Sci., 52: 674-678.

Olsen, S.R., Cole, C.V., Watanable, F.S. and Dean, L.A. 1954. Estimation of available phosphorus in soil by extraction with sodium bicarbonate, U.S.D.A, 939, USA.

Opala, P.A., Othieno, C.O., Okalebo, J.R., Kisinyo, P.O. 2009. Effect of combining organic materials with inorganic phosphorus sources on maize yield and financial benefits in Western Kenya. Expert. Agril, 46: 23-34.

Piper, C.S. 1960. Soil and Plant Analysis. The University of Adelaide, Australia.

Reddy, M.S., Kumar, S. and Khosla, B. 2002. Biosolubilization of poorly soluble rock phosphates by Aspergillus tubingensis and Aspergillus niger. Bio.Reso. Tech., 84: 187-189.

Richard, L.A. 1954. Diagnosis and improvement of saline and alkaline soils. USDA Hand Book No. 60.

Sepat, S. and Rai, R.K. 2013. Effect of phosphorus levels and sources on 
productivity, nutrient uptake and soilfertility of maize (Zea mays)-wheat (Triticum aestivum) cropping system. Indian J. Agron., 58(3): 292-297.

Singh, H. and Reddy, M.S. 2011. Effect of inoculation with phosphate solubilizing fungus on growth and nutrient uptake of wheat and maize plants fertilized with rock phosphate in alkaline soils. European J. Soil Biol., 47: 30-34.

Snell, F.D. and Snell, C.T. 1955. Colorimetric method of analysis. 3rd Edn. Vol. II Van Nostrand Inc., New York.

Subbiah, B.V. and Asija, G.L. 1956. A rapid procedure for the estimation of available nitrogen in soils. Curr. Sci., 25: 259-260.

TIFAC. 2011. Techno Market Survey on Technologies for Utilization of Low Grade Phosphate Fertilizer. Technology Information, Forecasting and Assessment Council, Department of Science and Technology, Govt. of India. Tisdale, S.L., Nelson, W.L., Beaton, I.D. and Havlin, I.L. 1995. Soil fertility and fertilizers (5th edition). Prentice Hall of India Pvt. Ltd., New Delhi 45-79.

Vance, C.P. 2001. Symbiotic nitrogen fixation and phosphorus acquisition: plant nutriention in a world of decling renewable resources. Plant Physiol, 127: 390-397.

Vyas, K.G., Patel, A.M., Raval, C.H. and Bhatt, P.K. 2012. Effect of rock phosphate, biofertilizers and FYM on growth, yield and economics of wheat (Triticum aestivum L.) under North Gujarat condition. Adv. Res. J. Crop Improv., 3(2): 160-163.

Wang, Y.H., Cao, C.Y., Shi, R.H., Jiang, R.C. and Li, Z.H. 1993. The effect of combined application of organic manure and inorganic fertilizer on the $P$ supplying ability of calcareous as soil. J. Mining Agril. Univ., 16: 35-42.

Zafar, M., Abbasi, M.K. and Rehman, Z.U. 2011. Effect of combining organic materials with inorganic phosphorus sources on growth, yield, protein content and phosphorus uptake in maize at Rawalakot Azad, Jammu and Kashmir, Pakistan. Arch. Appl. Sci. Res., 3(2): 199-21.

Zaidi, A., Khan, M.S., Ahemad, M. and Oves, M. 2009. Plant growth promotion by phosphate solubilizing bacteria. Acta Microbiology Immunol. Hungarica, 56: 263-284.

\section{How to cite this article:}

Mali M. K., Meena R. H. and Gajanand Jat. 2017. Effect of Composted Rock Phosphate with Organic Materials on Yield, Nutrient Uptake and Soil Fertility after Harvest of Maize (Zea mays L.). Int.J.Curr.Microbiol.App.Sci. 6(6): 901-909.

doi: https://doi.org/10.20546/ijcmas.2017.606.106 